\title{
PENINGKATAN PRESTASI BELAJAR DAN KEMAMPUAN GROUP-WORK MELALUI KOMBINASI PEMBELAJARAN PEER LEARNING DAN BLENDED LEARNING
}

\author{
Annisa Ratna Sari \\ Jurusan Pendidikan Akuntansi
}

\begin{abstract}
Abstrak
Tujuan dilaksanakannya penelitian ini adalah: (1) meningkatkan prestasi belajar mahasiswa melalui kombinasi pembelajaran Peer Learning dan Blended Learning pada mahasiswa Pendidikan Akuntansi FE UNY, (2) meningkatkan kemampuan Group-work mahasiswa melalui kombinasi pembelajaran Peer Learning dan Blended Learning pada mahasiswa Pendidikan Akuntansi FE UNY. Penelitian ini dilaksanakan di Program Studi Pendidikan Akuntansi FE UNY. Penelitian ini merupakan penelitian tindakan kelas dengan pendekatan model Kemmis-Taggart. Penelitian ini didahului dengan mengembangkan perangkat pembelajaran Blended Learning yang dikombinasikan dengan Peer Learning untuk mata kuliah Bahasa Inggris. Selanjutnya pembelajaran Blended Learning digunakan dalam proses pembelajaran dan dikombinasikan dengan peer learning sebagai upaya untuk meningkatkan prestasi belajar dan kemampuan Group-work mahasiswa. Tahap-tahap penelitian tiap siklus meliputi: perencanaan, pelaksanaan tindakan, observasi, dan refleksi. Subyek penelitian ini adalah mahasiswa yang mengambil mata kuliah Bahasa Inggris pada semester khusus tahun akademik 2012/2013. Teknik pengumpulan data dengan menggunakan observasi, dan tes/penugasan. Analisis data menggunakan analisis deskriptif. Strategi pembelajaran Blended Learning yang dikombinasikan dengan peer learning terbukti berhasil memberikan manfaat dan meningkatkan Prestasi Belajar dan kemampuan Group-work yang dijabarkan dalam 7 aspek yaitu: peningkatan prestasi, munculnya keberagaman pendapat, peningkatan kemampuan berbahasa, peningkatan kemampuan bertanya, rasa bertanggung jawab terhadap kesuksesan seluruh anggota kelompok, dan kemampuan bekerja dalam tim/grup.
\end{abstract}

Kata kunci: prestasi belajar, kemampuan group-work, blended learning, peer learning

\section{PENDAHULUAN}

Selama ini di Indonesia strategi pembelajaran yang populer dilakukan adalah pembelajaran tradisional, yaitu pembelajaran berbasis kelas (klasikal) dengan menggunakan metode ceramah. Dalam pembelajaran klasikal, proses belajar mahasiswa terikat oleh dimensi ruang dan waktu, artinya mahasiswa harus berada dalam ruang dan waktu yang sama dengan teman sekelas dan dosennya untuk melakukan kegiatan pembelajaran. Jika mahasiswa tidak mampu datang pada salah satu kegiatan perkuliahan, ini berarti bahwa mahasiswa tersebut akan kehilangan kesempatan untuk mendapatkan pengetahuan dan skill yang baru. Oleh karena itu, perlu dicari alternatif untuk pembelajaran klasikal yang bisa mengatasi masalah tersebut tanpa menghilangkan 
perasaan ikatan sosial antara mahasiswa dengan teman sekelasnya maupun antara mahasiswa dengan dosennya. Sedangkan dengan metode ceramah saja, mahasiswa juga menjadi pasif dalam memilih sumber belajar tambahan di luar sumber belajar yang disediakan oleh dosen karena mahasiswa berpendapat bahwa dosen pasti akan menjelaskan materi melalui ceramah di kelas. Padahal dosen tidak seharusnya menjadi satu-satunya sumber belajar, terutama di era digital dewasa ini, dimana sumber belajar bisa diperoleh dengan relatif mudah melalui bantuan teknologi informasi ataupun belajar melalui kolaborasi dan bekerja sama dengan teman sebayanya.

Berdasarkan hasil pengamatan pengajar terhadap mahasiswa Pendidikan Akuntansi kelas Internasional yang pada tahun ajaran 2012/2013 ini sedang mengambil mata kuliah Bahasa Inggris dengan menggunakan pembelajaran tradisional, mahasiswa terlihat kurang aktif dalam mencari sumber belajar lain selain yang sudah disediakan oleh dosen. Berdasarkan hasil observasi pengajar dalam dua kali pelaksanaan pembelajaran di dalam kelas yang dilakukan oleh mahasiswa, kelas terlihat cukup hangat. Dosen sangat terampil dalam meng-handle kelas dan sesekali mahasiswa mengajukan pertanyaan kepada dosen. Akan tetapi, tidak semua mahasiswa terlibat secara aktif untuk mengeluarkan pendapat ataupun sekedar mengajukan pertanyaan. Bahkan ketika dosen melempar pertanyaan untuk membuat suasana kelas lebih hidup, hanya mahasiswa tertentu saja yang bersedia berpartisipasi menjawab pertanyaan. Ketika mahasiswa tidak mau bertanya ataupun mengeluarkan pendapat, hal ini dapat mengindikasikan banyak kemungkinan. Pertama, mahasiswa mungkin malu atau tidak punya keberanian untuk mengungkapkan pernyataan maupun pertanyaan di depan teman-teman dan dosennya. Kedua, mahasiswa mungkin belum mampu untuk berpikir secara kritis dan diduga belum mempersiapkan diri di kelas dengan belajar sebelum masuk ke kelas. Hasil observasi juga menemukan indikasi bahwa beberapa mahasiswa sebenarnya mempunyai pengalaman yang cukup bagus terhadap topik yang sedang dibahas di kelas, akan tetapi tidak mau berbagi pengetahuan (knowledge sharing) dengan teman di kelasnya jika tanpa diminta oleh dosen walaupun sebenarnya mereka terlihat nyaman untuk berbagi ketidaktahuan dengan teman sebayanya.

Guna meyakinkan tentang apa yang sebenarnya menjadi masalah, maka peneliti menyebarkan angket kepada 10 orang mahasiswa, dan disimpulkan bahwa mahasiswa sebenarnya sudah melakukan peer learning tidak terstruktur, dan belum 
mendapatkan manfaat yang maksimal dari hasil peer learning tersebut. Perilaku mahasiswa ini diduga sudah berlangsung cukup lama.

Blended Learning pada dasarnya adalah suatu sistem belajar yang memadukan antara belajar secara face to face (bertemu muka/klasikal) dengan belajar secara online (melalui penggunaan fasilitas/media internet). Ada beberapa pendapat yang berbeda dari para ahli yang menentukan prosentase untuk masing masing cara, baik itu yang sifatnya face to face atau online. Sloan (dalam Avgerinou, 2008) menyebutkan bahwa sebuah pembelajaran dikatakan menggunakan strategi Blended Learning apabila 30-80\% dari desain dan implementasi pembelajaran baik dalam hal isi maupun penyampaiannya dilakukan secara online.

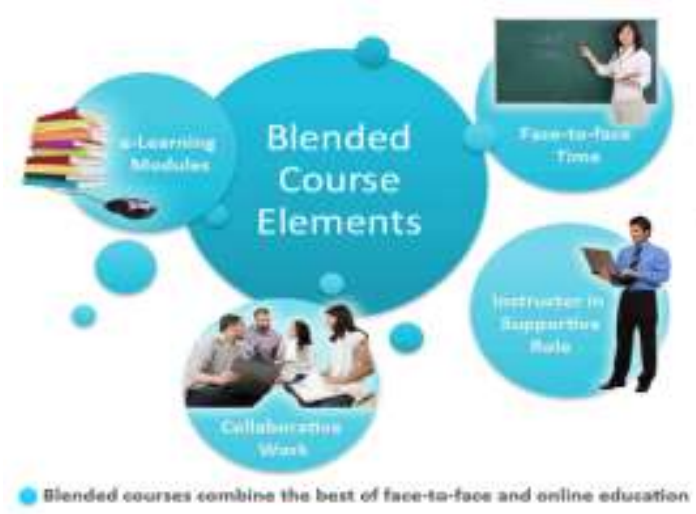

Gambar 1. Ilustrasi blended learning

(http://www.lll-ndu.com/Home/

OnlineBlendedLearning)

Blended Learning dapat diartikan sebagai sebuah sistem belajar mengajar yang memadukan pembelajaran berbasis teknologi dan informasi dengan pembelajaran berbasis kelas/tatap muka dengan beberapa keunggulan sebagi berikut: pendekatan belajar yang beragam, lebih mudah dalam mengakses pengetahuan, adanya interaksi sosial, pembelajaran yang bersifat pribadi, menghemat biaya, dan mudah dalam revisi (Akhmad Faizal, 2011). Akhmad Faizal lebih lanjut menjelaskan dalam pembelajaran Blended Learning, siswa tidak hanya mengandalkan materi yang diberikan oleh guru, tetapi dapat mencari materi dalam berbagai cara, antara lain, mencari ke perpustakaan, menanyakan kepada teman kelas atau teman saat online, membuka website, mencari materi belajar melalui search engine, portal, maupun blog, atau bisa juga dengan media media lain berupa software pembelajaran dan juga tutorial pembelajaran.

Graham (dalam Avgerinou, 2008) menjelaskan tiga alasan penting kenapa seorang pengajar lebih memilih mengimplementasikan Blended Learning dibandingkan pembelajaran online maupun klasikal, yaitu: pedagogy yang lebih baik, meningkatnya akses dan fleksibilitas, serta meningkatnya biaya-manfaat. Tabel di bawah ini dapat menunjukkan perbandingan kekuatan dan kelemahan dari pelaksanaan pembelajaran tradisional/face 
to face dan online yang dijadikan pijakan pendapat Graham diatas:

Tabel 1. Perbandingan kekuatan dan kelemahan antara pembelajaran online dan pembelajaran tradisional/face to face

\begin{tabular}{|c|c|c|}
\hline & $\begin{array}{l}\text { Online } \\
\text { (Asynchronous) }\end{array}$ & $\begin{array}{l}\text { Tradisional/ } \\
\text { Face to } \\
\text { Face (f2f) }\end{array}$ \\
\hline $\begin{array}{l}\text { Kekua- } \\
\text { tan }\end{array}$ & $\begin{array}{l}\text { Fleksibilitas par- } \\
\text { tisipasi mahasis- } \\
\text { wa terjadi dalam } \\
\text { waktu dan tem- } \\
\text { pat yang nyaman } \\
\text { bagi mahasiswa } \\
\text { Partisipasi semua } \\
\text { mahasiswa ber- } \\
\text { partisipasi dikare- } \\
\text { nakan kurangnya } \\
\text { hambatan waktu } \\
\text { dan tempat } \\
\text { Kedalaman re- } \\
\text { fleksi- mahasiswa } \\
\text { memiliki waktu } \\
\text { yang lebih untuk } \\
\text { mempertimbangk } \\
\text { an respon mereka } \\
\text { secara lebih hati- } \\
\text { hati dan lebih } \\
\text { menyeluruh }\end{array}$ & $\begin{array}{l}\text { Interaksi ma- } \\
\text { nusia - mudah } \\
\text { untuk mengi- } \\
\text { kat dan mem- } \\
\text { bentuk kehadi- } \\
\text { ran sosial dan } \\
\text { kepercayaan } \\
\text { dalam lingku- } \\
\text { ngan f2f } \\
\text { Spontanitas - } \\
\text { rantai ide yang } \\
\text { terkait dan ke- } \\
\text { mungkinan pe- } \\
\text { nemuan yang } \\
\text { cepat sangat } \\
\text { diharapkan } \\
\text { Partisipasi - } \\
\text { tidak semua } \\
\text { dapat berparti- } \\
\text { sipasi dikare- } \\
\text { nakan adanya } \\
\text { hambatan wak- } \\
\text { tu dan individu }\end{array}$ \\
\hline $\begin{array}{l}\text { Kele- } \\
\text { mahan }\end{array}$ & $\begin{array}{l}\text { Spontanitas } \\
\text { rantai ide yang } \\
\text { terkait dan kemu- } \\
\text { ngkinan penemu- } \\
\text { an yang cepat } \\
\text { tidak diharapkan } \\
\text { Penundaan- ma- } \\
\text { hasiswa mungkin } \\
\text { menyerah atau } \\
\text { menunda untuk } \\
\text { berpartisipasi se- } \\
\text { cara online } \\
\text { Interaksi manusia } \\
\text { - tidak mudah }\end{array}$ & $\begin{array}{l}\text { Fleksibili-tas- } \\
\text { Karena alasan } \\
\text { keterbatasan } \\
\text { waktu, penga- } \\
\text { jar mungkin } \\
\text { tidak dapat } \\
\text { meraih diskusi } \\
\text { yang menda- } \\
\text { lam sesuai kei- } \\
\text { nginan }\end{array}$ \\
\hline
\end{tabular}

untuk mengikat dan membentuk kehadiran sosial dan kepercayaan dalam lingkungan online

Berdasarkan berbagai macam definisi tentang strategi Blended Learning diatas dapat disimpulkan bahwa Blended Learning merupakan sebuah strategi belajar mengajar yang bertujuan untuk mencapai tujuan pembelajaran dengan cara memadukan pembelajaran berbasis teknologi dan informasi dengan pembelajaran berbasis kelas/tatap muka, dengan prosentase penyampaian materi $30-80 \%$ dilakukan secara online.

\section{a. Peer Learning}

Blended Learning merupakan strategi pembelajaran yang sedang popular pada masa sekarang.Begitu banyak manfaat yang bisa diambil oleh guru melalui pemanfaatan starategi ini.Salah satunya adalah mempromosikan kegiatan kolaborasi dan kooperasi antar peserta didik dalam belajar, baik untuk aspek kognitif, afektif, maupun psikomotor.

Manusia pada dasarnya terlahir sebagai individualis, akan tetapi dalam hidupnya manusia tidak bisa bekerja sendiri. Manusia harus bersosialisasi dan bermasyarakat dengan manusia 
laindalam mencapai tujuan hidupnya, tidak terkecuali dalam belajar. Dengan belajar, manusia menjadi mampu untuk meningkatkan kualitas hidupnya; dan untuk belajar, manusia memerlukan bantuan dari orang lain baik secara langsung maupun tidak langsung (melalui perantara mesin). Salah satu contoh bentuk kerjasama manusia dalam belajar adalah melalui PeerLearning.

Peer Learning terjadi ketika setiap mahasiswa menjadi tergantung terhadap mahasiswa lain untuk kesuksesan belajarnya. Ketergantungan disini merujuk pada kegiatan aktif mahasiswa bekerja dalam kelompokkelompok (baik berpasangan maupun kelompok yang lebih besar lagi) melalui sharing pengalaman dan pengetahuan untuk meraih tujuan belajar mereka. Guna membuatnya lebih terstruktur, dosen perlu berpartisipasi dalam memperkenalkan dan merancang konsep pembelajaran yang mampu menstimulus terjadinya peer learning.

Peer Learning adalah suatu hal yang berbeda dengan Peer Tutoring.Peer Learning adalah " a twoway reciprocal learning activity in which there is mutual benefit to the parties involved" (Keppell et al, 2006).
Jadi dalam hal ini belajar merupakan aktivitas berbagi pengetahuan, tidak ada yang mendominasi satu sama lain (berkedudukan sama). Lebih lanjut Keppell menjelaskan dua jenis Peer Learning, yaitu:

(1) Formal Peer Learning: secara implisit terjadi ketika peserta didik mendiskusikan materi ceramah, tugas, proyek, dan ujian di luar kelas

(2) Informal Peer Learning:secara eksplisit terjadi dalam kerja kelompok atau kelompok proyek yang terjadwal di dalam kelas

Sehingga dapat disimpulkan bahwa Peer Learning adalah merupakan aktivitas belajar yang dilakukan melalui berbagi pengetahuan (yaitu tidak ada yang mendominasi satu sama lain/berkedudukan sama) di dalam dan di luar kelas.

Ada beberapa pendapat yang menyebutkan manfaat dari Peer Learning ini.Jared Barber (2006) dalam sebuah mentoring seminar menyatakan bahwa Peer Learning mempunyai banyak manfaat, antara lain: (1) meningkatkan keikutsertaan dan prestasi, (2) keberagaman pendapat dapat memacu perkembangan intelektual, (3) meningkatkan 
kemampuan berbahasa,

meningkatkan kemampuan bertanya, (5) mempromosikan rasa bertanggung jawab terhadap kesuksesan seluruh anggota kelompok (saling ketergantungan yang positif), (6) meningkatkan kemampuan bekerja dalam tim/grup (kemampuan interpersonal, kemampuan me-manage grup, kemampuan inkuiri, kemampan me-manage konflik, dan kemampuan presentasi), (7) membentuk skill untuk kesiapan kerja. Sedangkan Keppell et al (2006) menyebutkan ada 3 manfaat dari Peer Learning, yaitu: (1) mempromosikan kemampuan yang dapat ditransfer ke dalam pelajaran yang lain dan dunia kerja, (2) mempromosikan belajar sepanjang hayat, (3) mempengaruhi kemampuan bekerja dalam tim dan kemampuan interpersonal yang dibutuhkan dalam dunia kerja.

\section{METODE}

\section{Desain Penelitian}

Penelitian ini merupakan penelitian tindakan kelas.Lewin (dalam Hopkins, 2011) menyatakan bahwa penelitian tindakan kelas merupakan metodologi untuk menginversi dan meneliti masalahmasalah sosial yang terjadi pada saat ini dan berguna untuk kemajuan teori dan perubahan-perubahan sosial.
Penelitian PTK ini merupakan hasil kolaborasi antara peneliti dengan dosen pengampu mata kuliah. Selama sebelum dan selama pemberian tindakan, peneliti bekerja sama dengan dosen pengampu. Hal ini dimaksudkan agar penelitian dapat berjalan sesuai dengan rencana yang telah disesuaikan dengan perumusan masalah yang ditemui selama sebelum tindakan.

Dalam penelitian ini, model Penelitian Tindakan Kelas yang diadopsi merupakan model penelitian tindakan dari Kemmis dan McTaggart. Pengertian siklus pada kesempatan ini adalah suatu putaran kegiatan yang terdiri dari perencanaan, tindakan, pengamatan dan refleksi. Siklus ini dapat diulangi lagi sesuai kebutuhan apabila peneliti merasa perlu untuk melakukan perbaikan-perbaikan aktivitas.

CYCLE 1

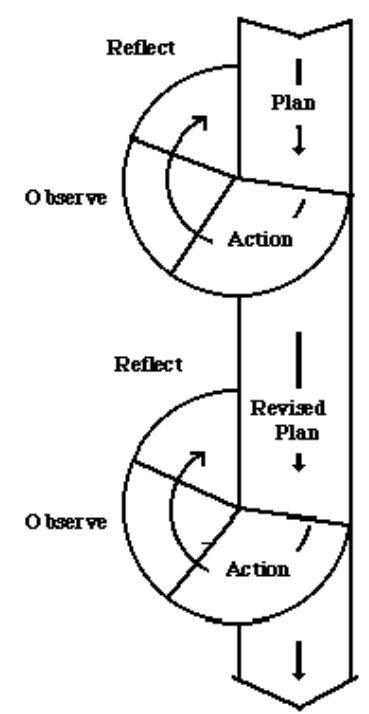

Gambar 2. Model Spiral Penelitian Tindakan dari Kemmis dan McTaggart 


\section{Subyek dan Obyek Penelitian}

Penelitian ini merupakan penelitian tindakan kelas sehingga tidak merupakan penelitian sampel ataupun populasi, akan tetapi perlu didefinisikan subyek dan obyek penelitian. Penelitian ini akan dilakukan terhadap semua mahasiswa Program Studi Pendidikan Akuntansi kelas Internasional pada Fakultas Ekonomi Universitas Negeri Yogyakarta disemester khusus tahun ajaran 2012/2013 yang mengambil mata kuliah Bahasa Inggris. Total jumlah mahasiswa tersebut adalah 12 orang. Seluruh mahasiswa pada kelas tersebut akan dijadikan subyek penelitian, sedangkan obyek penelitian ini adalah strategi Blended Learning untuk meningkatkan prestasi belajar dan kemampuan group-work antar mahasiswa.

\section{Perencanaan Penelitian}

Penelitian tindakan kelas ini direncanakan akan dilaksanakan dalam beberapa siklus, dimana untuk tiap-tiap siklusnya terdiri dari empat tahapan yaitu perencanaan, pelaksanaan, observasi, dan refleksi. Kegiatan pembelajaran dengan strategi pembelajaran Blended Learning ini akan berlanjut ke siklus berikutnya apabila indikator keberhasilan belum tercapai. Penelitian tindakan kelas ini tidak ditentukan akan dilaksanakan dalam jumlah siklus tertentu, tetapi didasarkan pada keberhasilan meningkatkan kemanfaatan Peer Learning. Hal ini senada dengan apa yang diungkapkan oleh Suharsimi Arikunto (2008), yaitu banyaknya siklus penelitian dalam penelitian tindakan kelas tergantung pada pencapaian tolok ukur, namun sebaiknya tidak kurang dari dua siklus.

\section{Teknik Pengumpulan Data}

Penelitian ini akan dilaksanakan selama bulan Juli 2013. Siklus satu akan dilaksanakan pada bulan Juli 2013 minggu ke-3, siklus dua akan dilaksanakan pada bulan Juli 2013 minggu ke-4. Teknik pengumpulan data penelitian meliputi:

a. Tes dan Penugasan

Teknik ini dipilih untuk mengumpulkan nilai mahasiswa untuk masing-masing topik (tiap-tiap minggu). Hasil penilaian untuk masingmasing topik kemudian dijumlahkan dan dicari nilai rata-ratanya untuk mendapatkan nilai belajar masingmasing siklus. Data nilai mahasiswa ini akan digunakan sebagai bagian untuk mengevaluasi keberhasilan peningkatan prestasi belajar mahasiswa melalui kombinasi pembelajaran Blended Learning dan Peer Learning .

b. Observasi

Teknik observasi dilakukan untuk mencatat dan mengamati proses belajar mahasiswa baik untuk mencatat 
jalannya kegiatan belajar mengajar, maupun untuk mengukur indikator kemampuan group-work mahasiswa yang meliputi: (1) munculnya keberagaman pendapat,

meningkatnya kemampuan berbahasa, (4) meningkatnya kemampuan bertanya, (5) munculnya rasa bertanggung jawab terhadap kesuksesan seluruh anggota kelompok (saling ketergantungan yang positif), (6) meningkatnya kemampuan bekerja dalam tim/grup.

\section{Uji Validitas dan Reliabilitas}

Penelitian ini merupakan penelitian kualitatif sehingga perlu dilakukan uji kredibilitas atau uji kepercayaan terhadap data hasil penelitian kualitatif. Teknik yang akan digunakan adalah dengan menggunakan triangulasi data. Menurut Sugiyono (2005), triangulasi data dapat diartikan sebagai pengecekan data dari berbagai sumber dengan berbagai cara dan berbagai waktu.

\section{Teknik Analisis Data}

Data hasil tes dan penugasan sebagai bentuk prestasi belajar mahasiswa, dan hasil observasi kemampuan group-work mahasiswa akan dianalisis secara deskriptif kuantitatif.

\section{Indikator Keberhasilan}

Keberhasilan penelitian tindakan diketahui dari perubahan yang terjadi sebelum, selama dan sesudah pelaksanaan tindakan. Apabila terjadi peningkatan nilai atau perbaikan situasi, maka secara umum tindakan dinyatakan berhasil (Mulyatiningsih, 2012). Artinya, Penelitian Tindakan Kelas bisa dinyatakan berhasil berapapun peningkatannya asalkan jelas bahwa peningkatan tersebut terjadi murni disebabkan oleh strategi, pendekatan, model, ataupun metode yang dipakai selama tindakan. Berdasarkan pendapat tersebut, maka keberhasilan penelitian ini dikatakan berhasil apabila (1) setiap mahasiswa dinyatakan lulus, yaitu mendapat skor diatas 56 (hal ini didasarkan pada peraturan akademik UNY tahun 2011, dimana mahasiswa dinyatakan lulus jika mendapatkan skor minimal 56 atau jika dikonversi dalam skor huruf menjadi C) (2) setiap mahasiswa yang mengikuti mata kuliah Bahasa Inggris ini mampu menunjukkan peningkatan kemampuan group-work sehingga indikator manfaat peer learning terpenuhi.

\section{HASIL DAN PEMBAHASAN}

\section{Deskripsi Subyek Penelitian}

Subyek Penelitian merupakan mahasiswa Program Studi Pendidikan Akuntansi kelas Internasional yang 
mengambil mata kuliah Evaluasi

Pendidikan pada semester Genap tahun 2011/2012. Program Studi ini berada di bawah Jurusan Pendidikan Akuntansi, Fakultas Ekonomi, Universitas Negeri Yogyakarta (UNY). Fakultas Ekonomi UNY merupakan fakultas yang relatif baru. Fakultas ini merupakan salah satu fakutas hasil pecahan dari Fakultas Ilmu Sosial dan Ekonomi UNY yang terjadi berdasarkan Peraturan Menteri Pendidikan Nasional Nomor 23 Tahun 2011 tentang Organisasi dan Tata Kerja UNY pada tanggal 22 Juni 2011 (http://fe.uny.ac.id). Pemecahan fakultas terjadi sebagai akibat dari adanya tuntutan perkembangan dunia kerja.

Program studi Pendidikan Akuntansi kelas Internasional yang berada di bawah Jurusan Pendidikan Akuntansi ini mulai dibuka tahun 2009. Saat ini, program studi tersebut telah memiliki kurang lebih 91 mahasiswa dengan uraian: 15 mahasiswa angkatan 2009, 18 mahasiswa angkatan 2010, 28 mahasiswa angkatan 2011, dan 30 mahasiswa angkatan 2012. Kegiatan perkuliahan diselenggarakan dalam 2 bahasa (bilingual), yaitu menggunakan bahasa Indonesia dan bahasa Inggris.

\section{Analisis Data}

1) Pelaksanaan Penelitian Tindakan Kelas

$\begin{array}{rrrr}\text { Mata } & \text { kuliah } & \text { Bahasa } & \text { Inggris } \\ \text { merupakan } & \text { mata } & \text { kuliah } & \text { yang }\end{array}$

mengajarkan kepada mahasiswa pengetahuan dan kemampuan untuk mempergunakan bahasa Inggris.Mata kuliah ini merupakan mata kuliah yang cukup penting di Program Studi Pendidikan Akuntansi Universitas Negeri Yogyakarta utamanya pada kelas Internasional sebagai bekal memasuki dunia kerja baik di sektor pendidikan dan pengajaran, maupun sektor bisnis.

\section{a) Perencanaan}

Persiapan tindakan yang dilakukan dalam penelitian ini adalah sebagai berikut: penyusunan rencana pembelajaran, lembar kegiatan mahasiswa, format penilaian, alat evaluasi dan lembar observasi.

b) Pelaksanaan

Pelaksanaan tindakan yang akan dilakukan :

- Dosen menyiapkan materi perkuliahan yaitu bahan ajar, tugas dan alat evaluasi (latihan maupun kuis).

- Seminggu sebelum pelaksanaan pembelajaran, dosen memberi tugas kepada mahasiswa untuk mempelajari atau membaca materi (topik) yang tersedia, baik dari buku, maupun dari situs yang memang sudah dirancang khusus untuk mata kuliah ini, yaitu: 
https://sites.google.com/site/eng

lishpakt2011i/home.

- Mahasiswa melaksanakan tugas untuk mempelajari materi tersebut secara mandiri, ataupun secara berkelompok sesuai panduan penugasan dari dosen. Ada beberapa macam tugas yang digunakan, yaitu: diskusi online, mengajukan pertanyaan pada situs web untuk tiap topik, memberi tanggapan atas pertanyaan teman yang diajukan di situs web untuk tiap topik, mengajukan pertanyaan dan memberi tanggapan atas pertanyaan teman di kelas, latihan di kelas maupun latihan mengerjakan soal secara online.

- Dosen mengoreksi hasil pekerjaan mahasiswa, baik tugas yang berbentuk hardcopy maupun tugas yang berbasis online. Selanjutnya mendokumentasikan hasilhasilnya dalam lembar penilaian. Khusus untuk diskusi online, dosen memberikan kesempatan kepada mahasiswa terlebih dahulu untuk menjawab pertanyaan temannya, baru kemudian menyimpulkan di akhir.
- Dengan metode ceramah, latihan, diskusi dan tanya jawab; dosen mengungkapkan kembali pengembangan materi dan memberikan penugasan untuk melatih pemahaman konsep mahasiswa.

- Bersama-sama mahasiswa dosen menyimpulkan materi perkuliahan yang telah di pelajari.

- Dosen melakukan evaluasi diri/ refleksi untuk mengamati keberhasilan penerapan model pembelajaran Peer Learning dan Blended Learning yang telah dilakukan.

\section{c) Observasi}

Selama kegiatan belajar mengajar Tim peneliti melakukan observasi terhadap proses pembelajaran dan melakukan pencatatan terhadap hal-hal penting selama proses dan kemunculan indikator-indikator kemampuan group-work untuk setiap siklusnya. Observasi terhadap proses pembelajaran dilakukan dengan menggunakan lembar observasi, alat bantu catatan lapangan, tape recorder dan dibantu oleh observer ke-2. Hasil observasi nantinya akan digunakan sebagai materi refleksi 
pelaksanaan siklus yang kemudian akan digunakan untuk menentukan jenis tindakan perbaikan pada kegiatan belajar mengajar siklus berikutnya.

\section{d) Analisis dan Refleksi}

Data hasil observasi untuk indikator-indikator kemampuan group-work setiap siklus dianalisis. Apabila berdasar hasil observasi pelaksanaan tindakan belum terlihat optimal baik dari hasil maupun pelaksanaan proses pembelajaran, maka perlu diimplementasikan siklus yang selanjutnya sampai didapatkan hasil yang optimal sesuai dengan indikator keberhasilan yang sudah dicanangkan. Hasil refleksi di tiap siklusnya akan digunakan untuk merencanakan dan mengimplementasikan tindakan siklus kedua, siklus ketiga dan siklus berikutnya.

2) Hasil Pelaksanaan Penelitian Tindakan Kelas

Berdasarkan pengimplementasian pembelajaran Blended learning dan Peer learning dalam pembelajaran didapatkan hasil-hasil sebagai berikut:

\section{a) Prestasi belajar}

Tabel 2. Hasil tes dan penugasan Aspek Prestasi Belajar

\begin{tabular}{lcccccc}
\hline $\begin{array}{l}\text { Prestasi } \\
\text { belajar }\end{array}$ & Pra-PTK & $\begin{array}{l}\text { Siklus } \\
\text { Siklus 2 }\end{array}$ & Sil \\
\hline & 0 & $0 \%$ & 6 & 50 & 12 & $100 \%$ \\
$>56$ & & & & $\%$ & & \\
$($ Lulus) & & & & & & \\
\hline$<56$ & 12 & $100 \%$ & 6 & 50 & 0 & $0 \%$ \\
(Tidak & & & & $\%$ & & \\
Lulus) & & & & & & \\
\hline
\end{tabular}

Berdasarkan hasil tes dan penugasan didapatkan hasil bahwa setelah pelaksanaan siklus 1 terdapat separuh dari jumlah mahasiswa yang mempunyai prestasi belajar yang memenuhi persyaratan lulus mata kuliah, sedangkan setelah pelaksanaan siklus 2, semua mahasiswa mampu memenuhi persyaratan lulus mata kuliah.

\section{b) Kemampuan Group work}

Terdapat 6 kriteria yang digunakan untuk mengukur munculnya aspek kemampuan group-work yang timbul sebagai manfaat pelaksanaan Peer Learning dan Blended Learning. Kriteria-kriteria tersebut kemudian digunakan sebagai pedoman untuk menilai jumlah mahasiswa yang mendapatkan atau mampu menunjukkan manfaatpeer learning antara sebelum penelitian, penelitian siklus 1, dan penelitian siklus 2 . 
Tabel 3. Hasil Observasi Aspek Peer Learning

\begin{tabular}{|c|c|c|c|c|c|c|}
\hline \multirow[t]{2}{*}{ KRITERIA } & \multicolumn{2}{|c|}{ Pra-PTK } & \multicolumn{2}{|c|}{ Siklus 1} & \multicolumn{2}{|c|}{ Siklus 2} \\
\hline & $\sum$ & $\%$ & $\sum$ & $\%$ & $\sum$ & $\%$ \\
\hline $\begin{array}{l}\text { 1. Perkemba- } \\
\text { ngan intelek- } \\
\text { tual melalui } \\
\text { munculnya } \\
\text { keberagam- } \\
\text { an pendapat }\end{array}$ & 2 & $\begin{array}{l}16,67 \\
\%\end{array}$ & 5 & $\begin{array}{l}41,67 \\
\%\end{array}$ & 10 & $\begin{array}{l}83,33 \\
\%\end{array}$ \\
\hline $\begin{array}{l}\text { 2. Peningkatan } \\
\text { kemampuan } \\
\text { berbahasa } \\
\text { Inggris }\end{array}$ & 0 & $0 \%$ & 7 & $\begin{array}{l}58,33 \\
\%\end{array}$ & 10 & $\begin{array}{l}83,33 \\
\%\end{array}$ \\
\hline $\begin{array}{l}\text { 3. Peningkatan } \\
\text { kemampuan } \\
\text { bertanya }\end{array}$ & 2 & $\begin{array}{l}16,67 \\
\%\end{array}$ & 5 & $\begin{array}{l}41,67 \\
\%\end{array}$ & 12 & $100 \%$ \\
\hline $\begin{array}{l}\text { 4. Adanya rasa } \\
\text { bertanggung } \\
\text { jawab terha- } \\
\text { dap kesuk- } \\
\text { sesan selu- } \\
\text { ruh anggota } \\
\text { kelompok }\end{array}$ & 0 & $0 \%$ & 6 & $50 \%$ & 10 & $\begin{array}{l}83,33 \\
\%\end{array}$ \\
\hline $\begin{array}{l}\text { 5. Peningkatan } \\
\text { kemampuan } \\
\text { bekerja da- } \\
\text { lam grup }\end{array}$ & 2 & $\begin{array}{l}16,67 \\
\%\end{array}$ & 7 & $\begin{array}{l}58,33 \\
\%\end{array}$ & 12 & $100 \%$ \\
\hline $\begin{array}{l}\text { 6. Terbentuk- } \\
\text { nya skill } \\
\text { ber-bahasa }\end{array}$ & 0 & $0 \%$ & 7 & $\begin{array}{l}58,33 \\
\%\end{array}$ & 10 & $\begin{array}{l}83,33 \\
\%\end{array}$ \\
\hline Rata - Rata & 1 & $\begin{array}{l}8,33 \\
\%\end{array}$ & 6 & $50 \%$ & 11 & $\begin{array}{l}91,67 \\
\%\end{array}$ \\
\hline
\end{tabular}

\section{Pembahasan}

Berdasarkan analisis data yang sudah disajikan diatas ditemukan bahwa kombinasi pembelajaran peer learning dan blended learning mampu memberikan banyak manfaat sebagai berikut: peningkatan prestasi, munculnya keberagaman pendapat, peningkatan kemampuan berbahasa, peningkatan kemampuan bertanya, rasa bertanggung jawab terhadap kesuksesan seluruh anggota kelompok, kemampuan bekerja dalam tim/grup, pembentukan skill berbahasa. Berbagai indikator manfaat tersebut setelah di-observasi mampu meningkat antara sebelum dan sesudah tindakan. Hal ini sejalan dengan penelitian yang dilakukan Elsie S.K. Chan yang berjudul, "An Innovative Learning Approach: Integrate Peer-to-Peer Learning Into Blended Learning" menunjukkan bahwa melalui pendekatan peer-to-peer learning berbasis blended learning, mahasiswa berkolaborasi, bertanggung jawab terhadap belajarnya, dan memperdalam pemahaman dalam konteks belajarnya. Sehingga dapat dinyatakan bahwa terjadi peningkatan kemampuan mahasiswa dalam hal prestasi belajar dan kemampuan group-work antara sebelum implementasi pembelajaran Peer Learning dan Blended Learning, dan setelah pengimplementasian Strategi Blended Learning (siklus 1, siklus 2, dan siklus 3).

\section{SIMPULAN}

Berdasarkan hasil penelitian dan pembahasan yang telah diuraikan, dapat diambil simpulan: Implementasi Pembelajaran Peer Learning dan Blended Learning mampu meningkatkan prestasi belajar dan kemampuan group work dalam 6 aspek berikut ini: peningkatan prestasi, munculnya keberagaman pendapat, peningkatan kemampuan berbahasa, peningkatan kemampuan bertanya, rasa 
bertanggung jawab terhadap kesuksesan seluruh anggota kelompok, dan kemampuan bekerja dalam tim/grup.

\section{DAFTAR PUSTAKA}

Ahmad Faizal. (2011). Upaya Peningkatan Keaktifan Siswa Melalui Implementasi Blended Learning Pada Pembelajaran Biologi Kelas Xi Smait Nur Hidayah Kartasura. Skripsi: FKIP UNS.

Barber, Jared. (2006). Peer Learning Groups.Mentoring Seminar handout.Diakses melalui http://math.arizona.edu/ lega/485585/Peer_Learning_Groups_JB.pdf tanggal 31 Maret 2013.

Carol B. McKnight. (2000). Teaching Critical Thinking through Online Discussions. Educause Quarterly, Number 4 2000.Diakses melalui http://eac595b.pbworks.com/f/mackni ght+2000+questions\%5B1\%5D.pdf tanggal 16 Maret 2012.

David Hopkins. (2011). Panduan Guru: Penelitian Tindakan Kelas. Yogyakarta: Pustaka Pelajar.

Elsie S.K. Chan. (2012). An Innovative Learning Approach: Integrate Peer-toPeer Learning Into Blended Learning. IJGE: International Journal of Global Education - 2012, Vol.1 Issue 1.

Endang Mulyatiningsih. Perspektif Penelitian Tindakan Keals. Modul Pelatihan PTK. Diakses tanggal 17 Mei 2013 melalui alamat url: http://staff.uny.ac.id/sites/default/files /pengabdian/dra-endangmulyatiningsih-mpd/3cplpg-ptk.pdf

Irzan Tahar dan Enceng.(2006). Hubungan Kemandirian Belajar dan Hasil
Belajar pada Pendidikan Jarak Jauh.Jurnal Pendidikan Terbuka dan Jarak Jauh, Volume. 7, Nomor 2, September 2006, 91-101.

Kana Hidayati dan Endang Listyani.(2010).

Instrumen

Kemandirian Belajar Mahasiswa.

Diakses melalui:

http://staff.uny.ac.id/sites/default/files /penelitian/Kana\%20Hidayati,\%20M. Pd./Pengembangan\%20Instrumen.pdf tanggal 17 Maret 2012.

Keppell, Mike., Au, Eliza., Ma, Ada., Chan, Christine. (2006). Peer Learning and Learning-Oriented Assessment in Technology-Enhanced Environments. Assessment \& Evaluation in Higher Education, Vol. 31, No.4, August 2006, pp. 453-464.

Maria D. Avgerinou. (2008).Blended Collaborative Learning for Action Research Training. Journal of Open Education, volume 4 No.1, 2008.

Murray Fisher, Jennifer King, dan Grace Tague.(2001). Development of a SelfDirected Learning Readiness Scale for Nursing Education. Nurse Education Today 21, p. 516-525. Diakses melalui http://ccnmtl.columbia.edu/projects/pl $3 \mathrm{p} / \mathrm{self}-$

directed\%20learning\%20scale\%20for \%20nurses.pdf tanggal16 Maret 2012.

Ozgen Korkmaz dan Ufuk Karakus. (2009). The Impact of Blended Learning Model on Student Attitudes Towards Geography Course and Their Critical Thinking Dispositions and Levels. The Turkish Online Journal of Educational Technology - TOJET, October 2009 volume 8 Issue 4.

Richard Paul dan Linda Elder. (2008). The Miniature Guide to Critical Thinking 
Jurnal Pendidikan Akuntansi Indonesia, Vol. XII, No. 1, Tahun 2014

Annisa Ratna Sari

$106-119$

Concepts and Tools. California: The

Foundation for Critical Thinking

Press.

Robert J. Stenberg dan Joan B. Baron.(1985). A Statewide Approach to Measuring Critical Thinking Skills.Educational Leadership, October 1985.Diakses melalui http://www.ascd.org/ASCD/pdf/journ als/ed_lead/el_198510_sternberg.pdf tanggal16 Maret 2012.

Suharsimi Arikunto. (2008). Penelitian Tindakan Kelas. Jakarta: PT. Bumi Aksara.

Sugiyono. (2005). Memahami Penelitian Kualitatif. Bandung: Alfabeta. 